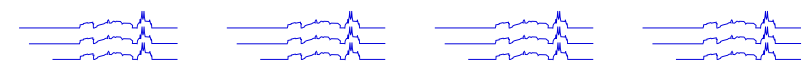

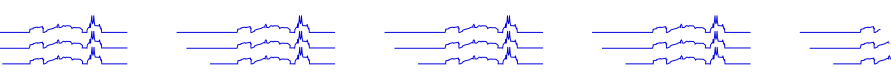

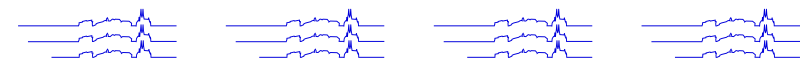

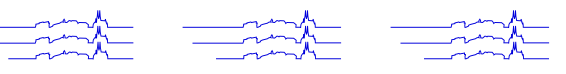
工玨统

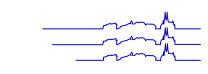
三证定

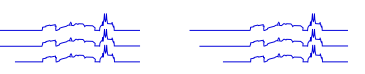

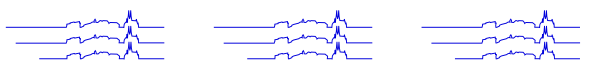

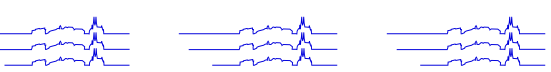

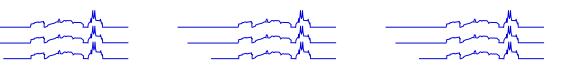
工些众

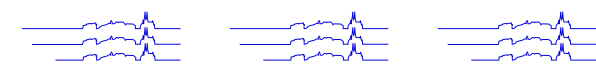

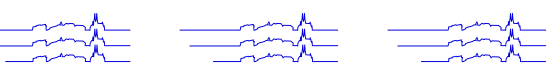

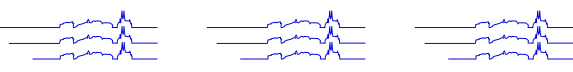

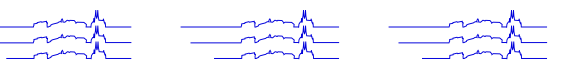
工证该 二姃婴 二证 二证

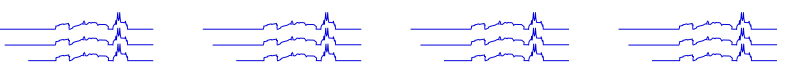
二证众

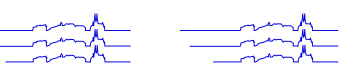
二妙

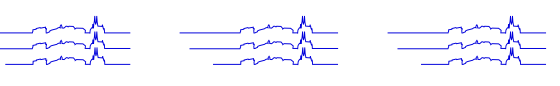

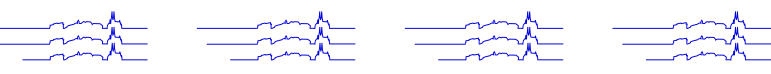

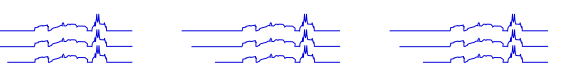

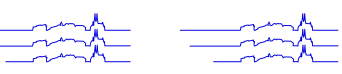
二玩

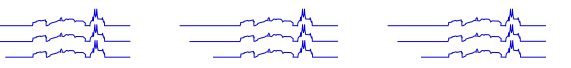
工证该 工该 二证该 二证资 二玩次 二证

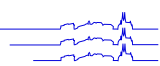
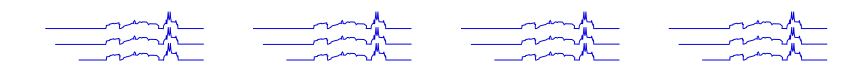
二证次 工证设 든순 工nd 二证该 三证次

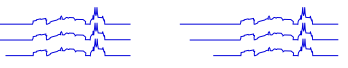

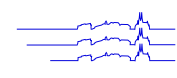

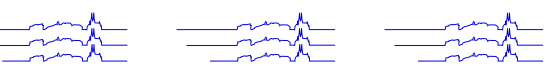

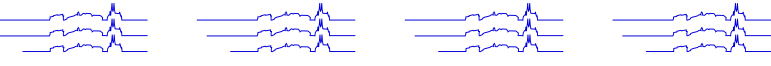

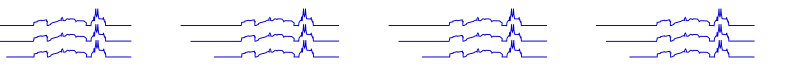
工证证 二琣 工永次 二证该 二 $2 \sin$

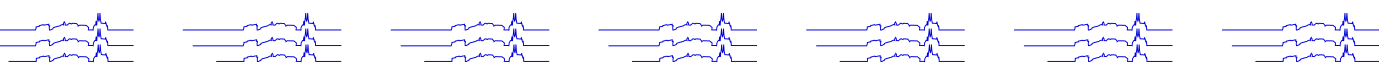

Simona Koryčánková, Anastasija Sokolova (eds.)

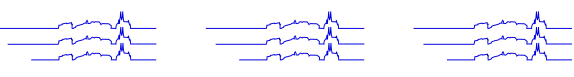

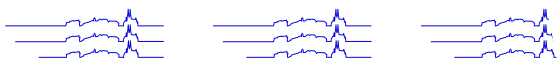

II A S A R Y K U II I V E R S I T Y PRESS 


\section{Current issues of the Russian language teaching XIV}

Simona Koryčánková, Anastasija Sokolova (eds.)

Masaryk University Press

Brno 2020 
Sborník prací pedagogické fakulty mu č. 276

řada jazyková a literární č. 56

Edited by: doc. PhDr. Mgr. Simona Koryčánková, Ph.D., Mgr. Anastasija Sokolova, Ph.D.

Reviewed by: Elena Podshivalova (Udmurt State University), Irina Votyakova (University of Granada)

(C) 2020 Masaryk University

ISBN 978-80-210-9781-0

https://doi.org/10.5817/CZ.MUNI.P210-9781-2020 


\title{
FACT AND ALLEGORY: TWO POLES IN THE REPRESENTATION OF WAR (ON THE EXAMPLE OF "WAR'S UNWOMANLY FACE” BY S. ALEXIEVICH AND "THE CURSED AND THE SLAIN" BY V. ASTAFIEV)
}

\author{
Olga Gubskaya \\ Olga Jilevich
}

https://doi.org/10.5817/CZ.MUNI.P210-9781-2020-19

\begin{abstract}
The military actions of the 2oth century (Revolutions, the First and Second World Wars, the Cold War, the war in Kosovo, Chechnya, Iraq) left a terrifying mark on the history. The article discusses traditional and innovative forms of recreating the military context in the Russian and Russophone Belarusian military prose on the example of V. Astafiev and S. Alexievich's works.
\end{abstract}

Key terms

military prose, fact, document, artistic image, intertext, narrator, allegory, universality, allusion

\section{Introduction}

"The Great Patriotic War" is one of the prevailing themes of Soviet literature. Yet literary interest in the subject of war has continued through to the present period; time and distance encouraging reflection on enormity of this event, and its related existential questions: life or death, friend or foe, hope or despair, idea or ideology; and the fate of the individual in history.

During the Soviet period, state ideology remained a controlling restraint to authorial thought. Demise of the USSR afforded writers the opportunity of adopting individual creative approaches to a literary interpretation of history.

Among such writers, are Svetlana Alexievich, winner of the 2015 Nobel Prize in Literature; and Viktor Astafiev, a winner of numerous Soviet awards, and in 1996 State Prize of the Russian Federation.

Astafiev's war experience 1941-1945, laid the foundation for later creative biographical history writing; guided by an urgent need to declare, before the people, the truth of the war. In this regard, Joseph Brodsky is noted, for his observation, that every social tragedy "is, in one way or another, a biographical event".

The prose writing of Astafiev presents a complex phenomenon. Astafiev's "The Cursed and the Slain", 1992-93, may be seen as a further development in the war prose of Russian literature. It does not fit the genre-specific form of the classic novel; rather the narrative follows a form of "philosophical allegorization", which enables the author to evade open moral and ethical judgments, while encouraging the reader to establish a personal interpretation of truth.

The aim of this paper is to examine how these recent innovative forms of literature have enabled new understandings of "The Great Patriotic War". A description of this writing approach - working with fact and allegory - will be the main objective of this research, with focus on a comparative study of the work of Alexievich, and Astafiev.

The research aims to be complementary to the work of literary scholars that are actively studying the features of Alexievich's work. These include, in Belarus, Professor L. Sinkova, who devoted a series of papers to study this question in the book "Belarusian Superliterature"; and in Russia, Lev Anninsky.

Achieving the aim requires solving some tasks: 
- to trace the features of the functioning of fact and allegory in the narrative of Svetlana Aleksievich and Victor Astafiev'novels as an artistic and aesthetic means of text and its constructive factor;

- to reveal the specifics of the personality image and the principles of structuring the character system in the military prose of writers;

- to present author's strategies in revealing the artistic conception of the world and man, solving moral, ethical, philosophical and ontological problems.

\section{Theoretical background}

In philosophy, the nature of war, in particular the dilemmas of "peace-war", "violence-non-violence" were studied in different periods from Aristotle to P. Sorokin. As we know, there are several concepts of philosophers on the nature of war and peace:

1) L. Tolstoy, M. Gandhi, M.-L. King, A. Fortune, A. Huseynov and others hold the view that war is an absolute evil. The war must be completely abandoned. Following the Christian doctrine of nonviolence, L. Tolstoy actively advocated "absolute peace". American researcher A. Fortune believes that even in life-threatening situations, it should not use violence in response (Fortune, 2004).

M. Gandhi and M.-L. King continued the concept of L. Tolstoy. They developed pacifism - a movement for world peace in its various variants. They offered an alternative to war in a nonviolent form of resistance to the enemy, its meaning is not in obedience, but in the ability of the parties to find a compromise and mobilize the strength of spirit of each person. This approach includes a range of measures - diplomatic talks, peaceful speeches, the use of public speaking techniques, special methods of nonviolent action.

2) According to I. Ilyin and S. Bulgakov, war can be fair. It may take place. It is a sad necessity. Therefore, it is necessary to remember military charity, to educate those who must defend the Fatherland.

In contrast to L. Tolstoy, I. Ilyin criticizes his absolute denial of violence and war. He emphasizes courage and heroism as key values in Orthodox, secular and military ethics. The scientist believes that it is necessary to respect his enemy, but he does not oppose war. According to him, war is a difficult necessity, but he also has a negative attitude towards pacifism (Ilyin, 2005).

3) War can only take place as a last resort, although it can be fair. In resolving controversial political issues, it is necessary to give preference to diplomatic methods, education of high morality, as well as the strength of faith and spirit. V. Solovyov, G. Niebuhr, A. Kovalev, F. Meyers are the proponents of this concept. V. Solovyov believes that the meaning of nonviolence in the settlement of political relations should not be denied in any case. He writes that the war can be resorted to only in the most exceptional cases.

According to A. Kovalev, harmony in society is the coexistence of the violence and non-violence, good and evil. He believes that good and evil are governed by nature itself, violence and evil are needed within reasonable limits (Kovalev, 2001).

Thus, the listed concepts are based on the interpretation of the experience of the twentieth century. On the one hand, researchers completely deny the war, express the need to convey to society by various means the idea of non-violent resistance and diplomatic resolution of international conflicts. On the other hand, some modern scholars perceive the experience of nonviolence either as a utopia or as a doctrine.

The life and work of the Belarusian writer S. Alexievich and the Russian writer V. Astafiev are united by pacifist views, the desire to convey to the reader the terrible consequences of hostilities and the desire to urge him to prevent war in the future. 


\section{Basic methodology}

The present study was mainly based on the comprehensive and includes hermeneutic, comparativetypological, cultural and historical methods, a method of holistic analysis of a literary text, methodical developments on the problem of theory of genres.

"War's Unwomanly Face" by Svetlana Aleksievich and "The Cursed and the Slain" by Victor Astafiev raised moral, ethical, worldview problems, rethought through the prism of fact and allegory were the material of this paper.

\section{Description of the issue}

\section{Fact as an artistic image in the "War's Unwomanly Face" by Svetlana Alexievich}

Primarily it is worth nothing that the fact in the work isn't recorded by the writer, but the character a direct participant of the event who tells his story to a reader. The author acts only as a listener in such situation, sometimes asking questions to the narrator. Thus, Svetlana Alexievich creates an oratorio novel - a work with lots of voices which tell their story of suffering, the story of life. As it was mentioned in my article «Specificity of perception of the russian-language literature of Belarus (on the example of Svetlana Alexievich's book "Time of second hand"), "the genre of an oratorio novel was professionally felt by the writer, a graduate of the faculty of journalism of BSU, and was perceived as a starting point for a creative beginning. The fact as a base of the plot was as a "brand" and the base of her creative strategy at the same time" (Gubskaya, 2019, p. 318).

The first book "War's Unwomanly Face" (1984) was published by Svetlana Alexievich exactly in the style of the oratorio novel. This documentary story, based on the interview with soviet women, who took part in the Great patriotic war, initially was published in the magazine "Oktyabr" (1984); some more chapters were published in the magazine "Neman" at the same year. In 1985, the work was published as a separate edition. Considering that the book immediately received a large number of prestigious state awards, such as the Literary Award named after Nikolai Ostrovsky The Union of Writers of the USSR (1984), the award of the magazine "Oktyabr" (1985), the Literary Award named after Konstantin Fedyn The Union of Writers of the USSR (1985), the Linin Komsomol Award (1986), it becomes clear that both the Soviet reader and representatives of the public sector like it. And this is not surprising, because it is not the writer himself who speaks in the book, but his characters - living witnesses of military events, and besides, not men, but women.

I can't say that the literary story of a woman at a war was mentioned firstly only in the work of S. Alexievich. In 1969 was published the story "But the dawns here are quiet" by Boris Vasilyev, telling about the fates of five girls-antiaircrafters and their commander during the Great patriotic war. In addition, in 1977 was published the book "I am from the Fiery Village" by A. Adamovich (together with Ya. Bryl and V. Kolesnik), in which firstly in the Belarussian literature "live voices" began talking about the war and the people who stayed alive in that "fiery villages", burned to the ground by the Nazis. Svetlana Alexievich calls Ales Adamovich her mastermind and teacher: "Once the book "I am from the Fiery Village" felt into my hands by A. Adamovich, Ya. Bryl, V. Kolesnik. Such a shock I've got only once when I was reading Dostoevsky. However, there is an unusual form: the novel is compiled by the voices of the life itself. It is from everything that I've heard in my childhood, it's from everything that sounds at the street, at home, at a café, at a trolley nowadays. So! The circle is closed. I've found that I was looking for. Foresaw. Ales Adamovich became my teacher (Alexievich, 2019, p. 9). Perhaps this is why she took a quote from A. Adamovich's novel "The War Under the Roofs" as the name for her first book: "War's Unwomanly Face". But nothing was remembered more, harshly, terribly and more beautiful than our mothers' faces”. In fact, this idea by A. Adamovich became the concept of the work of S. Alexievich: shows female story of the war publicly, honestly without any hesitation in a realistic manner. 
In her diary notes to the book, she writes: "Everything that we know about the war, we know with the "male" voice. We are all in captivity of "male's" views and "male's" feelings of the war. "Male's" words. However, the women are silent. Nobody except me asked my grandmother. My mother. Even those who were at the front are silent. If they suddenly begin to remember, then they're telling not "women's war", but “man's". Adjust to canon” (Alexievich, 2019, p. 9). It becomes obviously that the creative objective of S. Alexievich is to destroy this canon. The objective of our small research is to trace what methods the writer uses to display the "female" war, how do female facts of the war differ from men's?

To solve this objective it is important to understand what meaning the writer puts into the concept of "female war", "female memory of the war". Let's turn into the fragment of the text, where the author tries to give the explanation: "In optics, there is the concept of „aperture“ - the ability of the lens is worse, it is better to capture the captured image. Therefore, the female memory of the war is the most "fast-moving" in terms of tension of feelings, in pain. I would better say that the female war is worse than "male". Men hide under the history, the facts, the war captivates them as an act of ideas' confrontations, different interests, but women are captured by feelings (Alexievich, 2019, p. 17). It is obvious that the writer uses the principle of contrast for the verbal illustration of her concept, antithesis, in fact, selects contextual anthonymic pairs: male - female, facts - feelings. This principle is also supported in the titles of the chapters. For example, "Grow up, girls, you're still young", "About the smell of fear and a case of sweets", "About dolls and guns", "About horses and birds", "About the male boots and the female hats", "About the girl's treble and sailor superstitions", "About the silence of horror and the beauty of fiction", "About a small life and a great idea" etc. It is important to note that this principle emphasizes S. Alexievich journalistic education. The writer starts to contact with a reader from the first lines, written in capitals. The titles in her book performs the pragmatic (expressive) function: they demonstrate the author's personal priorities, her philosophical attitude; quite clearly reflect the picture of the inner and outer world of the acting hero of the story, and originally, intriguingly presented with reality. We can say also that such titles perform the role of a mediator between the text and a recipient (a reader), using the volume of his background knowledge about the life and the war, affecting on the reader's emotions.

At the same time, such emotional, imaginative titles immerse us in the rather harsh reality of the war, set forth through the fact recorded in the memory of the heroes of the book. But the whole secret of the title is that the reader searches for the keywords (sign words) in the text that were indicated in it, and on which the author emphasized (or rather, made a bid). These words-signs should probably stop the author's attention in and return to the name, rethinking of which should cause reflection after reading the text.

For example (due to the small volume of the research), we turn to a series of stories, united under the title "About the smell of fear and a suitcase of sweets". Certainly, the word-sign here will be "a suitcase of sweets", although and the synesthesia "smell of fear" is no less emotional. Therefore, what do we see in the text? The facts about the war recorded in the female memory who went to the front from an early age. Nadezhda Vasilyevna Anisimova, a medical officer of a machine gun group, tells that she found a wounded soldier on the neutral line and dragged him, fixed with the belt to her arm, during eight hours. In the result of this accident, firstly she got five days in prison for the absence without leave and then the Medal of Honor. "When I was nineteen I had the Medal of Honor. When I was nineteen my hair became gray. When I was nineteen during the last fight, my both lungs were shot; the second bullet went between two vertebras. The legs were paralyzed... And I was considered dead..." - told the participant of the war (Alexievich, 2019, p. 66). It's a creepy story, but the title has "a suitcase of sweets"! The reader is looking for a word-sign further. Further is the story of Albina Gantimyrova, a senior sergeant, a scout. She got her first Medal of Honor, because she was able to raise confused soldiers from the shelter at the beginning of the battle: "The battle started. Heavy fire. 
The soldiers lay down. The command: "Go ahead! For the Motherland!", but they are lying. I took away my hat in order to see me: a girl stood up... And they all stood up and we went into the battle" (Alexievich, 2019, p.69). Then we read the story of the cryptographer Lyubov Charnaya, who, having become pregnant at the very beginning of the war, was forced to get rid of the child, and then went to the front to avenge the unborn. Further, the reader will find another female story of the partisan messenger Maria Savitskaya-Radyukevich, who ran to assignments through German posts with a small child. And then a few more: about the pilot Anna Dubrovina; the commander of a platoon of machine gunners Lyubov Lyubchik; the partisan Anna Strumilina, who, due to Jewish descent, lived in the ghetto, and having lost her parents, she went to the partisans. Moreover, almost at the end of the series of stories, the reader meets the story of the medical assistant Maria Tikhomirova, in which she tells about a suitcase of sweets: "I'm in the village where I was assigned after a specialized school, got my first money. There was money, and I bought a whole suitcase of chocolates for that money. I knew that I won't need money in the war" (Alexievich, 2019, p. 81).

This exact keyword search mechanism that concentrates all readers' attention on the text - the reader will get acquainted with the facts of the war, and his mind will look for a "suitcase of sweets", perhaps even try to imagine a wrapper. Moreover, this "suitcase of sweets" will be not just a fact of a real story (this is only for a storyteller), but an artistic image, symbolizing a calm, peaceful life. Here we can state the process of changing a real fact into an artistic image - this is a feature of the artistic manner of writing S. Alexievich. As the Belarusian literary critic L. Sinkova notes, "A precisely recorded real fact begins to manifest itself as an artistic image, and thus, this change in the functional role of the document into the artistic unit should be considered as a genre-forming factor" (Sinkova, 2009, p. 95).

Why is there a change in the role of fact in the work? This is due to the peculiarity of the perception of the fact by the writer herself, her creative concept. "I'm interested not in the event itself, but in the event of feelings. Let's just say - the soul of the event. Feelings are the reality for me," writes S. Alexievich (Alexievich, 2019, p.16). This exact event of feelings is visualized into a female poetic image. Female war is a story of the struggle not only with the enemy, but also with oneself, overcoming one's own fears and stereotypes. Of course, men also had to struggle with fear, but women had a number of female desires and experiences that were not customary to talk about in traditional works of war: to sleep on sheets, not on the ground; eat a completely white loaf; walk in high heels; wash hair; put on women's underwear. Moreover, all these everyday concepts for peacetime, recorded as facts of military life in the works of S. Alexievich, turn into artistic images, symbols of peaceful life. The writer understands this perfectly, explaining the nature of such a transformation as follows: "Memories are not a passionate or dispassionate retelling of a vanished reality, but a new birth of the past, when time turns back. First of all, it is a creativity" (Alexievich, 2019, p. 11).

Svetlana Aleksievich records the "birth of a new past" talentedly, after years rethought by the war participants. In addition, this rethinking colors the gray truth of the war with bright colors: mixes tarpaulin boots with high-heeled shoes, the sound of wheat and the sounds of a German guns, rough tunics and thin cotton of lingerie. This shows the desire of the recorded fact to "sovereignty", independence from military literary discourse, and the image of the narrator is revealed in the harmonious combination of the "body" of the writer and the "soul" of the direct storyteller. The story is told to the reader by a nurse, aviator, partisan, but the reader doesn't hear a clear truth of the participant in the military events, but the voice of the narrator (a storyteller), who successfully adapts the story in harmony with the author's artistic concept. "We are writing a book of time together. Everyone screams his truth. A nightmare of shades. Moreover, you need to hear all of this, and dissolve in all of this, and become like this all. In addition, at the same time do not lose yourself. Combine street speech and literature. The difficulty is that we speak about the past in nowadays 
language. How to pass the feelings of those days to them?" - S. Alexievich asks a question (Alexievich, 2019, p.16). We see the answer in her works.

If we use the terms of Y. I. Yavchunovsky, the doctor of art history, who wrote that "two trends determine the special role of the narrator in the documentary literature: the pursuit for "sovereignty" and submission to the dictatorship of reality" (Yavchunovsky, 1974, p. 178), then the author, and together with him, and the narrator, successfully combine the "pursuit of the fact for sovereignty" and to a sufficient extent "submission to the dictates of reality." The dictatorship of reality can be traced in the history of almost every character speaking to us through the same author's trick the inclusion in the story of a kind of intertext in the form of political slogans of the prewar and wartime periods. Let us turn to the test: "From childhood, from school time, we heard: "Girls, drive a tractor!", "Girls, drive an airplane!” (Alexievich, 2019, p. 59); "When I was still in seventh grade, an airplane flew to us. There were those years, imagine, in the thirty-six year. Then it was a curiosity. Then a call appeared "Girls and boys - on a plane!" Of course, as a Komsomol member, I was in the forefront. I immediately signed up for the flying club" (Alexievich, 2019, p. 60); "And then the speaker began to play:" Get up, the huge country...” The first time I heard this song. "I think I'll recover and immediately go to the front" (Alexievich, 2019, p. 71); "We were educated that the Motherland and we are one and the same" (Alexievich, 2019, p. 81). Obviously, this intertextuality not only turns us into historical time, but also emphasizes the character of that time: a variety of opportunities for everyone, the dynamic development of society, and the most importantly, the dominant "slogan" form of communication, when someone addresses to the masses, controls them. This fact of reality, implicitly presented by the author, quite clearly characterizes the pre-war time.

\section{Allegory as a narrative structure of "The Cursed and the Slain" by V. Astafiev}

In contrast to S. Aleksievich, one of the distinguishing features of the poetics of military prose by V. Astafiev is the use of conditional forms of artistic generalization, logarithm. In the field of philosophical generalizations, he often turns to an associative-allegorical form of embodiment of an idea. Therefore, in the novel "The Cursed and the Slain" by Astafiev, the role of conditional forms is so significant - allegories, symbols, allusions, leitmotifs, metaphors, parables, etc. Allegory in Astafiev's novel doesn't a single trope but a whole narration, whose elements contain symbolic meanings underlying its second meaning" (Jilevich, 2020, p. 62).

The narratively-compositional center of the epic novel "The Cursed and the Slain" by V. Astafiev is the first book - "Devil's Pit". The allegorical image of the barracks-pit acquires special semantic meaning. According to the author, the barracks is the torture for eighteen-year-old young men of the 21st reserve infantry regiment. This has a deep allegorical overtone. L. Annensky, for example, sees in the meaning of the barracks "camp", "camp hell", "hell", "primordial cave", as the emerging "gloomy experience of the Gulag". ("What's the point of war? Where is its reason? For what sin this retribution has come? What is it with people, with their nature, with their soul? ... What kind of spoiled damnation leads people astray?" (Annensky "Literaturnaya gazeta", March 3, 1993). A. Neluyer sees the allegory of the barracks-pit as the figurative expression of All Russia of the day: "Who is crying, who is tormented, and who is dying in this heavy fog? What if the whole country is our devil's pit?" (A. Neluyer "Segodnya", March 2, 1993).

And in fact - the place is hellish: "indifferent evil people", kicking out recruits from cars, "hoarse yelling", "obscurity", "universal howling or moaning", "terrible howling”, tormented "not of one's will and hunting " stupidly walking human columns. Is it any wonder that "obedience to fate" immediately took possession of one of V. Astafiev's characters - Leshka Shestakov, who was thrown into this nightmare by mobilization, and his soul was immediately "visited anything that should be settled in his pocket and prison - all agreement with everything that happens." (Astafiev, 2019, p. 66) The writer further constantly compares the barracks with the prison. Indeed, even Leshka 
understands the word "barracks" as not frightening, not disturbing, but contemptible." "Everything is harsh here, everything is on the level of a modern cave, therefore, cave life, cave life ... Leshka tells himself: "As if in a den", but didn't feel any confusion, only dull humility ... oppressed and two more desires languished over it - I wanted to breathe fresh air and eat." (Astafiev, 2019, p. 70) V. Astafiev sees an allegory "pit-barracks" as a devilish, infernal meaning: poor, half-buried in the ground, "that neither the flame, nor the curse of the earth, nor the powers of heaven took these cellars," "only time was disastrous for them - they connected they dutifully settled into the sandy soil with all their meager belongings, with the people swarming in them, as if ominous coffins were doomed into the bottomless abysses" (Astafiev, 2019, p. 83). To this gloomy picture is a smoked pole of bunks, whitening at the ends with "bones", as if they had already visited the grave, "with the gray that appeared on them".

The author, using allegory, creates the depressing atmosphere of the barracks, smelling of sulfur, "rot, dust and sharp young urine". "The willow mats were teeming with bugs and lice ... the mats broke, sharply, like legs, pierced the body, the soldiers, having collapsed them, slept in the sand, in the dust, without undressing." (Astafiev, 2019, p. 92)

It was not for nothing that L. Annensky noted the author's remark: the Ob Sea is now splashing at the location of the 21st regiment. It means the memory of the "devil's hole" itself is washed off the face of the earth. The critic sees the allegory of the author as religious: is it not God's providence? On the other hand, is it possible that everything was washed away and forgotten, and the ladies based on the beach, not suspecting that somewhere here young Siberian guys "go to pot" and only Ob waters were hidden on century ugly traces of their hardships and suffering? ” (Astafiev, 2019, p. 104).

If the author sends his heroes-recruits to agricultural work and softens his accusatory tone ("funny warriors", "no less funny girls"), then he gives them a quiet calm. In the future, they will go to a hellish place of a completely different kind, and a completely different "universal howl".

A striking feature of V. Astafyev's military novel "The Damned and The Forgotten" is that the writer, in philosophical and allegorical form, begins the story of the war from the months preceding the sending of recruits to the front. By constant retreats into the past of his heroes, he reveals and justifies the main property of the existence of people in a country that has survived 17 years, the civil war, collectivization, political repression. The barracks is a collective image of soldiers, which combines the features of a conditional literary image that carries an ironic and allegorical function in the novel, although it remains a realistic character that preserves all the features of a national hero.

The collective image of the soldiers in the barracks thinks together - with "one head", speaks with the same words: "How many heads Melnikov will take away, how many words he will waste in vain," thought foreman Shpator and senior sergeant Yashkin. Collective thinking is always easier, because individuality can cause a lot of trouble, it "hides, dissolves, it seems to be covered by a high wave of unanimity, and it is no longer visible, it is like that elusively small amount that can be neglected.

Trying to depict the behavior of many lives, the author experiences the same temptation, and then his heroes have one head for all and one nervous system. For example, "the people banged and finally woke up", "the people moved approvingly, laughed briefly", "thinking completely about the house, the guys startled with the whole crowd", "the audience looked down at once", "and the audience on the court is completely on the side of the defendant". This is a combination of human diversity in one cohesive reaction, not an ordinary device that conveys the general mood. It had to confirm and prove quantitatively that not only one thought indignantly about the groaning, dirty reality, but also all soldiers were completely yearned and indignant.

Soldiers resemble "miserable prisoners from pre-revolutionary times" or vagrants. They are depersonalized by a terrible life, turning into a speck of dust in a „gray, thick cloud of dust.“ Torn from a house and piled up in a heap, placed in a cold and dirty room, they soon become indifferent to everything except food and sleep. Now this "hunched old people with dead eyes, wheezing from a 
cold". Even giants, like Kolya Ryndin, became "closer to heaven than to earth". "Kolya Ryndin began to fall off his face, brick stiffness came off his square scruff, glass to his cheeks, but on his cheeks a blush appeared less and less, except during working in the cold. The get fall ..." (Astafiev, 2019, p. 106) But even before the war, "the lives of these people were mostly miserable, humiliating, impoverished, consisted of standing in lines, receiving rations, coupons, and even the struggle for the crop, which was immediately withdrawn in favor of society." (Astafiev, 2019, p. 112)

Having barely crossed the threshold of the barracks, they - "children of workers, children of peasants, special migrants, proletarians, scoundrels, thieves, murderers who didn't see anything human" - were brought to absolute depersonalization, and began to "believe" in a single friendly choir, struck by fear. Still, they were faced with a "basement rat life" and a society of people "turned into animals". A tragic collective attitude is felt everywhere. For example, when a burry minion of fate "half-Armenian-half-Jew" fighter Vaskonyan, who hadn't seen anything before the army "from a theater ogee", began to tell "fellow workers" about Count Monte Cristo, kings "children of workers, peasants" "reverently listened to fairy tales about the luxurious world." (Astafiev, 2019, p. 81)

The allegorical image of the barracks-pit likens to itself its inhabitants. They fit her by the same grimy, degenerated and accustomed to reality. The author is frank in describing the flea-infested people: "Leshka rummages under the linen, crawls under his armpits, catches creatures ..." (Astafiev, 2019, p. 145). The image of this parasite V. Astafiev pays considerable attention. This can be seen as an allegory: small, seemingly fearless; but for the most part, bringing death to people, lice are compared with those "enemies of the people", with those propagandists-communists who hid behind the back of the war, creating the appearance of work and ruining innocent people. "Our lice are brisk, with a round black ass, they tirelessly remind us of it, they have risen neither light nor dawn, they are working, and they are eating." Moreover, the author is sure that they did not have long to torment the person, soon they will all be "cursed and killed". "Captured beasts rest, paws in the belly of the fingers, turn them around if they knew how to scream, so they would wake everyone on the bridgehead with cries! ... But they have no mercy, these constant enemies of socialism: with a pinch, the signalman takes them out and lets them out, not at a long one - it will drop down at the feet and footstep them alive, bury: don't bite, don't eat your own, eat the fritz while he's still alive." (Astafiev, 2019, p. 205)

There are also group portrait characteristics: "sick miserable huddled on the lower bunks, pulled from a damp door, pulled from the damp floor, and how they were not punished ... they dragged all kinds of rags on themselves, wagged nests on the bunks. The stolen by the legs, thrown to the floor, repeatedly stubbornly crawled to the bunks ... if only not for the frost in the wet, doggy smelling pants." (Astafiev, 2019, p. 214)

The writer, who paints and curses the war half a century later, must have something substantial to add to our well-established, conservative understanding of things, he wanted to enlighten us, to bring to our side - the side of the accusation.

In the second book, the war in allegorical form showed "its bestial grin and an insatiable womb, absorbing thousands of human bodies daily." It describes the battle for one of twenty-seven bridgeheads, called Velikokrinitsky, on the right bank of the Dnieper („Great River“) during its crossing in the autumn of 1943; depicting terrible pictures of earthly hell in its authenticity and naturalism. This is also an allegory of the devil's pit, only it is located on the front line, the same situation as in the recent past: there are no products, no ammunition, no order. The operation from the left bank was led by criminally soulless officers, because of fear they did not participate in crossing the water barrier. The crossing scene is drawn expressively and sharply, with the help of vivid metaphorical images and expressive language: "No fantasy, no book, no film, no canvas will convey the horror that they feel thrown into the river, under fire, into a tornado, into smoke, into a stench, into fatal madness, in comparison with which the biblical fiery hell looks like a children's fairy tale with a fantastic horror <...>" (Astafiev, 2019, p. 317). In addition, the enemy kept pouring fire on the shore 
and water, in which a mess of people was swarming. "Old and young, conscious and irresponsible, volunteers and military enlistment offices mobilized, fines and guards, Russian and non-Russian they all shouted the same words: "Mom! Bozhechka! God" and "Guard!", "Help! ... ”And the machine guns slashed them and slashed, watered with colorful death trickles." (Astafiev, 2019, p. 317).

In the novel, V. Astafiev was reflected the process of deformation of discourses that ensured the legitimacy of the former political order. "Ideological decolonization" was accompanied by the appeal of peoples "to their old, traditional memory, selected, destroyed or distorted in their favor by the corresponding regime" (Nora, 2005, p. 397-398). The consequence of this process, according to P. Nora, is the reinterpretation of key historical events from the point of view of communities, groups, and layers that are affected by the rights, which, by offering their own version of events, constructed their identity (Ibid., p. 398). A similar kind of tendency is found in the novel, and its roots go back to the late Soviet period, when, despite the censorship restrictions, the desire to portray came to be known in the framework of the anti-communist version of traditionalism (A. Solzhenitsyn, V. Astafiev, V. Belov, etc.). "Simple man" as a victim of political power projects (Lipovetsky, 2012, p. 811). In "The Cursed and the Slain", V. Astafiev, already without regard to the prohibitions and conventions that have expired, puts this idea at the heart of the ideological concept of the novel. In his interpretation during the Great Patriotic War, the people confronted not only a foreign invader, but also hostile power.

The novelty of "The Cursed and the Slain" isn't only in the concept of war that contradicts the Soviet canon, no matter how it is interpreted - in the Orthodox or liberal anti-communist spirit, but in exposing the universal experience of pain, defenselessness, existential despair in the face of violence and death removed national and historical barriers.

\section{Results of the analysis and conclusions}

Thus, concluding my thoughts about the method of processing the fact by Svetlana Alexievich, I would like to note the following. Despite the fact that the documentary novel "The Unwomanly Face of War" is usually referred to as non-fiction literature, the artistic principle is quite clearly shows in it. The fact in the text is graded and plays a certain function: one category of facts, usually reflecting the "female history", demonstrates the pursuit of the narrator to "sovereignty"; another category of facts, demonstrating real historical discourse, subordinates the text to the dictates of reality. As a result, we get an exclusive, authorial material in which, the "little" person "writes his life" against the backdrop of real historical events, through small, memorable, dear, and understandable details only to him. At the same time, Svetlana Alexievich creates his literature "history - through the story of an invisible witness and participant" (Alexievich, 2019, p. 15).

In the novel "The Cursed and the Slain" V. Astafyev clothed his memories of the war in a philosophical and allegorical form. Allegory, as an "allegorical depiction of a speculative idea in an objective image" was necessary for the author to deeply comprehend the tragic reality of the twentieth century. A feature of the allegorical component of V. Astafyev's creativity is its repeatability, versatility and ramification. The allegorical layer allowed the writer to focus his thought, to raise it to the level of pure embodiment.

The results of the study can be used in the further study of the philosophical and allegorical novel from the standpoint of modern aesthetics, cultural studies, literary criticism, comparative studies, which, in turn, will deepen understanding of the modern literary process.

\section{References}

ALEXIEVICH, S. (2019). The Unwomanly Face of War [U voyny ne zhenskoye litso]. Moscow: Vremya. ASTAFIEV, V. (2019). The Cursed and the Slain. [Proklyaty i ubity]. Moscow: Azbuka. 
FORTUNE, A. (2004). Violence as Self-Sacrifice : Creative Pacifism in a Violent World. Journal of Speculative Philosophy, 3 (18), pp. 184-192. https://doi.org/10.1353/jsp.2004.0020

ILYIN, I.A. (2005). About resistance to evil by force [O soprotivlenii zlu siloyu]. The nightmare of evil good [Koshmar zlogo dobra]. Berdyaev, A. (ed.) Moscow: Nauka.

JILEVICH, O.F. (2020). Philosophical and allegoric novel: aesthetic and cultural intentions. [Filosofskoallegoricheskiy roman: esteticheskiye i kulturnyye intencii]. Retrieved from URL: https://rep.polessu.by/handle/123456789/18914.

GUBSKAYA, O.N. (2019). Specificity of perception of the Russian-language literature of Belarus (on the example of Svetlana Aleksievich's book „Time of second hand”) [Specifika vospriyatiya russkoyazychnoy literatury Belarusi (na primere knigi S. Aleksievich „Vremya sekond hend“)]. Retrieved from URL: https://rep.polessu.by/handle/123456789/14599.

KOVALEV, A.M. (2001). Method of spiritual production in the structure of society [Sposob dukhovnogo proizvodstva $v$ strukture obshchestva]. Moscow: Nauka.

LIPOVETSKIY, M. (2012). Soviet and post-Soviet transformations of the plot of internal colonization [Sovetskiye i postsovetskiye transformatsii syuzheta vnutrenney kolonizatsii]. There, inside. The practice of internal colonization in the cultural history of Russia [Tam, vnutri: Praktiki vnutrenney kolonizatsii v kulturnoy istorii Rossii]. Etkind, A., Uffelmann, D., Kukulin, I. (eds.). Moscow: Novoye literaturnoye obozreniye, pp. 8o9-845.

NORA, P. (2005). World Celebration of Remembrance [Vsemirnoye torzhestvo pamyati]. The memory of the war 60 years later. Russia, Germany, Europe [Pamyat' o voyne 6o let spustya: Rossiya, Germaniya, Evropa]. Moscow: Novoye literaturnoye obozreniye, pp. 391-402.

SINKOVA, L.D. (2009). The formation of documentary genre in journalism Svetlana Aleksievich [Stanovleniye dokumental'no-khudozhestvennogo zhanra v zhurnalistike Svetlany Aleksievich]. Vestnik BSU. Seriya 4, pp. 93-96.

YAVCHUNOVSKY, Y.I. (1974). Documentary genres: image, genre, structure of the work [Dokumentalnyye zhanry: obraz, zhanr, struktura proizvedeniya]. Saratov: Publishing house of Saratov University.

\section{Contact information}

Olga Gubskaya

ORCID ID: 00oo-0002-8066-4207

Belarus State Economic University

Faculty of International Business Communications

Department of Belorussian and Russian Languages

Partizanski Av, 26, Minsk, 220070

Republic of Belarus

o_gubskaya@mail.ru

Olga Jilevich

ORCID ID: 000o-0001-6044-2917

Polessky State University

Faculty of Economics and Finance

Department of Intercultural Communications

Republic of Belarus

Dnieprovskoi Flotillii st, 23, Pinsk, 225710

jilevitch@gmail.com 


\section{CONTENTS}

\section{METHODOLOGY ISSUES}

A Reading-Book in Russian Literature:

The Text Preparation and the First Opinion of its Use

Josef Dohnal

Poetic Text Of Vasily Shukshin - The Red Guelder Rose In Russian

As A Foreign Language Class.

Marianna Figedyová

Language Games in Teaching Russian as a Foreign Language

Olga Iermachkova

Katarína Chválová

Specificity of Language Material Selection for Introduction of Russian Imperative Mood in "Russian as a Foreign Language" Classes.

Elena Kolosova

Poetic Texts in Teaching of Russian on B1 Level

(On the Example of Working with Vocabulary Denoting Perception in the Poems

of $\mathrm{O}$. Březina and V. S. Solovyov).

Simona Koryčánková

Speaking Accuracy of Russian Language Learners in Czech Lower Secondary Schools. 46

Janina Krejčí

Use of Digital Technologies in Russian Language Teaching

Miroslav Půža

Integrating Poetry into the Foreign Language Classroom

from the Point of View of Second Language Acquisition 62

Tatiana Savchenko

Verbal Aspect in Teaching Russian as a Foreign Language.

Liudmila Valova

ISSUES OF LINGUISTICS

Metaphoric Representation of the Concept "Creative Process" in V. Nabokov's Novel

"The Gift".

Yuliya Golovnyova

Albina Novikova

Polyprefixal Verbs of Silence in Russian and Polish

Tatiana Kopylova

Liliia Kilina

Images of Sound in Original and Translated Poems by Boris Pasternak

Larisa Kryukova

Anna Khiznichenko 
The Structure of Professional Knowledge

and Construction of Terminological Dictionaries

Anna Glogowska

Piotr Michalowski

Features of Word Formation in Contemporary Mass Media Texts

(In Russian and Croatian Language)

Marina Radčenko

The Language Component of The Film "Serf" as a Reflection of the Linguistic Features of Modern Russian Colloquial Speech (Russian as a Foreign Language) 120

Evgeniya Rubtsova

Tatiana Romanova

Linguacultural Dominants in Modern Russian Media Word Creation .128

Nadezhda Samylicheva

Neuter Gender Diminutive Suffixes in Russian in Comparison to Czech

Anastasija Sokolova

Kateřina Strachotová

The syntactic functioning of the infinitive in the Russian and Czech languages.

Oxana Truhlarova

ISSUES OF LITERARY SCIENCE 152

Fact and Allegory: Two Poles in The Representation of War (on the Example of "War's Unwomanly Face" by S. Alexievich and "The Cursed and The Slain" by V. Astafiev) . 153

Olga Gubskaya

Olga Jilevich

The Space of Light and Darkness in the Context

of the Creative History of M.A. Bulgakov's Novel the Master and Margarita 163

Elena Kolysheva

Thoughts on Boundaries in the Russian Linguistic Consciousness:

Background and Traditions.

Maria Milovanova

Alexandra Matrusova

Comparison of Tongue Twisters in Czech and Russian Languages

Lenka Rozboudová

Evgeniia Korneeva

Formulations of Wishes in the Traditional Russian Folklore

and in the Internet Communication.

Oleh Tyshchenko 